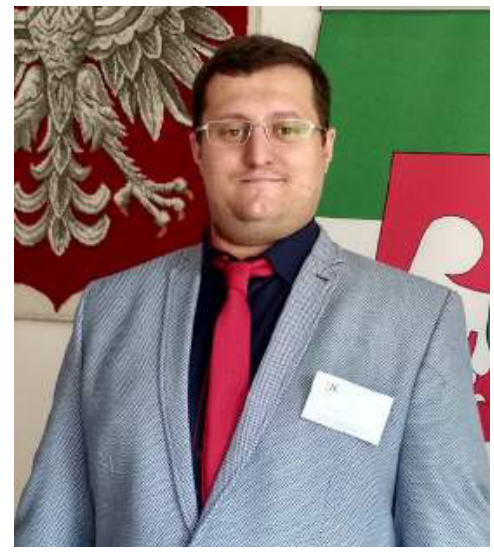

\author{
Петро Лещенко, \\ аспірант, \\ Полтавський національний педагогічний \\ університет ім. В. Г. Короленка \\ (м. Полтава, Україна)
}

Petro Leshchenko,

postgraduate student,

Poltava V. G. Korolenko National Pedagogical University

(Poltava, Ukraine)

peter.leshchenko@gmail.com

ORCID ID 0000-0001-7467-9704

Удк 37.012.3

\title{
КОМП'ЮТЕРНІ ІГРИ В НЕФОРМАЛЬНІЙ ОСВІТІ: ЗАРУБІЖНИЙ ДОСВІД ДОМАШНЬОГО НАВЧАННЯ
}

Анотація. У міжнародному освітньому просторі найбільш поширений вид неформальної освіти - домашнє навчання - набуває все більшої ваги. Відповідно до статистичних даних у Сполучених Штатах учнів, які здобувають освіту вдома, налічується близько 2 мільйонів. Комп'ютерні ігри займають особливе місце в домашній освіті, оскільки створюють віртуальне навчальне середовище, де знання здобуваються шляхом вирішення проблемних завдань.

Мета статті - вивчення зарубіжного, зокрема американського, досвіду використання комп'ютерних ігор для розвитку дітей в умовах домашньої освіти.

Завдання статті: схарактеризувати зміст комп'ютерних ігор, які найбільш часто використовуються в домашньому навчанні американських дітей; визначити позитивні ефекти використання комп'ютерних ігор у домашньому навчанні американських дітей.

Методи дослідження, які були застосовані для з'ясування сутності зарубіжного досвіду використання комп'ютерних ігор для розвитку учнів в умовах домашньої освіти: аналіз наукових джерел, класифікація та узагальнення фактів, системно-функціональний аналіз, нетнографія - дослідження блогів, веб сторінок фахівців, батьків домашніх учнів.

У статті визначено позитивні ефекти використання комп'ютерних ігор у домашньому навчанні: комп'ютерні ігри мають усі компоненти, що забезпечують ефективне навчання: мотивація, чіткі цілі та правила, інтерпретовані результати та постійний зворотний зв'язок; навчання і оцінювання функціонально пов'язані у грі, адже не можна перейти з одного рівня на інший, поки не будуть виконані всі необхідні завдання, таким чином зникає необхідність у тестуванні; комп'ютерні ігри стимулюють дітей до пошуку і приймання викликів, часто це створює додаткову мотивацію для гравців щодо оволодіння новими вміннями.

Використання комп'ютерних ігор у домашньому навчанні створює умови для розвитку в дітей умінь, необхідних для життя в XXI столітті, а саме: когнітивні, креативні, комунікативні, колаборативні та технологічні вміння. Вирішальним фактором корисності використання комп'ютерних ігор є те, що навчання стає привабливим для дітей, активізуючи в них природну потребу пізнання. Можливі ризики використання комп'ютерних ігор можна знівелювати, якщо дотримуватися гігієнічних вимог щодо організації навчання дітей.

Ключові слова: зарубіжний досвід, домашня освіта, комп'ютерна гра, освітні можливості, ризики.

\section{COMPUTER GAMES IN NON-FORMAL EDUCATION: FOREIGN EXPERIENCE OF HOME EDUCATION}

Abstract. In the international educational space, the most widespread form of non-formal education - home schooling is gaining more weight. According to the statistics, in the United States home-school students are about 2 million. An important reason that the number of home-school students tends to increase is the rapid spread of Information Technologies, in particular the Internet, so that learning content can be available anywhere, anytime. Among the vast amount of educational resources available through the network, video games occupy a special place in home education, as they create a virtual learning environment where knowledge is acquired through problem solving, which is important for decision-making in real-world situations.

The aim of the article is to elucidate the essence of foreign experience in the use of computer games for the development of students in the conditions of home education. Objectives of the article: to characterize the content of computer games that are most often used in the home schooling of American children; Identify the positive effects of using computer games in home schooling.

Research methods: analysis of scientific resources, classification and generalization of facts, system-functional analysis, netnography - research of blogs, web pages of specialists, parents of home students.

In the article the positive effects of using computer games in USA homeschooling are defined: video games have all the components that provide effective learning: motivation, clear goals and rules, interpreted results and constant feedback; training and evaluation are functionally related in the game, since you cannot move from one level to another until all the necessary tasks are completed, thus eliminating the need for testing; video games stimulate students to search and accept challenges. If 
game levels are difficult to master, then it often creates additional motivation for players to master new skills; games encourage carrying out risky actions. One of the biggest causes of passive participation of students in learning is fear of making a mistake in the eyes of their peers. While playing video games, students experience much less stress of risking losing than in traditional learning, if a student loses, then he gets the opportunity to play difficult game again, while avoiding negative evaluation.

The using of computer games in home schooling creates conditions for the development of children's skills necessary for life in the XXI century, namely: cognitive, creative, communicative, collaborative and technological skills. The decisive factor in the use of computer games is that learning becomes attractive to children, activating their natural need for cognition. The potential risks of using computer games can be alleviated if you adhere to hygiene requirements for the organization of training for children.

Keywords: homeschooling, computer game, blogging, educational opportunities, risks.

\section{ВСТУП}

Постановка проблеми. У міжнародному освітньому просторі неформальна освіта набуває все більшої ваги як гнучка і доступна фрорма навчання. Особливої уваги заслуговує найбільш поширений вид неформальної освіти - домашнє навчання.

Відповідно до статистичних даних у Сполучених Штатах учні, які здобувають освіту вдома, становлять близько 3,4\% від усієї кількості дітей шкільного віку: близько 2 мільйонів домашніх учнів [13].

За нещодавно зібраними даними, у Великій Британії кількість домашніх учнів становить понад 36000 дітей, але експерти говорять, що ця кількість може бути значно занижена [12].

Важливою причиною того, що спостерігається тенденція до збільшення кількості домашніх учнів, є стрімке поширення інформаційних технологій, зокрема Інтернету, завдяки чому навчальний контент може бути доступним у будь-якому місці і в будь-який час. Все, чого потребують домашні учні, - це смартфон, планшет або ноутбук. Серед величезної кількості навчальних ресурсів, доступних через мережу, відеоігри займають особливе місце в домашній освіті, оскільки створюють віртуальне навчальне середовище, де знання здобуваються шляхом вирішення проблемних завдань, що є важливим для прийняття рішень у реальних ситуаціях.

Спостерігається значна інтенсифікація зарубіжних досліджень, предметом яких є використання комп'ютерних ігор у домашній освіті. Застосування комп'ютерних ігор у різноманітних навчальних практиках зумовило виникнення й поширення в міжнародному освітньому просторі категорії «цифрового ігро-орієнтованого навчання» (англ. «digitalgame-basedlearning», абревіатура: «DGBL») після виходу в 2001 році першого видання книги М. Пренскі [16] під однойменною назвою «Цифрове ігроцентроване навчання». Її автор, американський педагог і письменник Марк Пренскі справедливо стверджував, що «в останні десятиліття XX століття відбулася глобальна технологічна революція, яка серйозним чином вплинула на пізнавальні процеси всіх суб'єктів навчання, а тому для задоволення пізнавальних потреб сучасних дітей (цифрових аборигенів) доцільно застосовувати комп'ютер і цифрові ігри в якості навчальних інструментів» [16, с. 12].

Аналіз останніх досліджень і публікацій. У вітчизняному освітньому просторі актуалізується проблема використання комп'ютерних ігор як одного з напрямів розвитку цифрової гуманістичної педагогіки [1], акцентується увага на фрормуванні цифрових умінь у майбутніх учителів початкових класів [2], актуалізується зарубіжний досвід реалізації різних підходів до використання комп'ютерних ігор у шкільному навчанні [4], популяризується використання навчальних ігор у початковій освіті, зарубіжний досвід використання відеоігор у навчанні старшокласників [7].

Головний експерт із вивчення ігор, професор Університету Вісконсін-Медісон Дж. П. Джі [10] дослідив позитивний вплив ігор на основні пізнавальні процеси, що поєднують розвиток почуття ідентичності, розуміння сенсу, вмінь сприймати й виконувати команди, вибирати рольові моделі та пізнавати світ.

За твердженням всесвітньо відомого дизайнера ігор Джейн Мак Гонігаль, відеоігри відповідають справжнім людським потребам, і майбутнє належить тим, хто може розуміти, проектувати та грати в ігри [15].

На важливість використання ігр у домашньому навчанні вказують К. Рольстад і К. Кессон [17], оскільки ігри надають можливості для формування різноманітних умінь, забезпечують позитивний емоційний стан, соціальну згуртованість, вирішення суспільних локальних і глобальних проблем. Багато домашніх учнів вивчили дивовижну різноманітність тем шляхом відеогри та спілкування з іншими щодо відеоігор, а також досягли високого рівня технологічної грамотності, граючи в комп'ютерні ігри [17].

Дослідження А. Ейхенбаума, Д. Бав'єєра та К. Шона [9] доводять, що позитивні ефекти комп'ютерних ігор (розвиток когнітивних, перцептивних умінь) уможливлюють їх використання в різноманітних освітніх практиках.

П. Грей [11], професор-дослідник Бостонського коледжу, наголошує, що інформація про шкідливі ефекти комп'ютерних ігор (викликають звикання та сприяють таким хворобам, як соціальна ізоляція, ожиріння і насильство) переважно міфічна, а позитивні ефекти є реальними (розвиток когнітивних, соціальних цифрових умінь).

Досвід домашнього навчання, зокрема навчальні досягнення учнів, умови організації домашньої освіти в США стали предметом дослідження А. Лещенко [4]. Теоретичні засади домашньої освіти в США, педагогічні погляди фрундатора і дослідника домашнього навчання Джона Холта вивчалися Л. Рубан [5]. Проте особливості використання позитивного потенціалу комп'ютерних ігор у домашньому навчанні залишилися поза увагою вітчизняних учених.

МЕТА І ЗАВДАННЯ ДОслІДЖЕННЯ. Мета статті: вивчення зарубіжного, зокрема американського, досвіду використання комп'ютерних ігор для розвитку дітей в умовах домашньої освіти.

Завдання статті: схарактеризувати зміст комп'ютерних ігор, які найбільш часто використовуються в домашньому навчанні американських дітей; визначити позитивні ефекти використання комп'ютерних ігор у домашньому навчанні американських дітей. 
МЕТОДИ ДОслІДЖЕНнЯ, які були застосовані для з'ясування сутності зарубіжного досвіду використання комп'ютерних ігор для розвитку учнів в умовах домашньої освіти: теоретичні (аналіз наукових джерел, класифікація та узагальнення фактів, системно-функціональний аналіз) та емпіричні (педагогічне спостереженя за гравцями в ході онлайн-ігор з учасниками з різних країн світу, етнографія - дослідження блогів, веб-сторінок фрахівців, батьків домашніх учнів).

\section{РЕЗУЛЬТАТИ ДОСЛІДЖЕННЯ}

Аналіз спілкування батьків домашніх учнів в інтернеті свідчить про розуміння ними можливостей позитивного впливу комп'ютерних ігор на розвиток дітей. Ось деякі, за свідченням батьків, з найбільш часто використовуваних у домашньому навчанні комп'ютерних ігор: «Повторюй і в пам'ять забивай» («Drill and Kill»); «Здоров'я та фрітнес» («Health and Fitness»), симуляційні ігри [18].

Коротко схарактеризуємо зміст названих ігор. «Повторюй і в пам'ять забивай» («Drill and Kill») - це рутинна «гра» на запам'ятовування, яка насправді мало приваблює учнів. Більшість дітей вибирають цю досить нудну комп'ютерну гру, надаючи їй перевагу в порівнянні з виконанням вправ у робочому зошиті [18]. Якщо вдома немає доступу до бігової доріжки, до боксерського рингу, індивідуального тренера чи фантастичного спортивного обладнання, то на допомогу приходять нові чутливі до руху комп'ютерні ігри, які успішно використовуються в домашній освіті. До таких ігор належить «Персональний Тренер» («UFC Personal Trainer» від Xbox Kinect i Wii Fit Nintendo). Ці ігри постачають віртуальних особистих тренерів та профеесійних спортсменів безпосередньо до місця проживання, оскільки вони моніторингують рухи, а експерти-аватари пропонують величезну кількість цінних порад гравцям. Дані щодо фізичної підготовки гравців зберігаються та доступні для аналізу й вимірювання досягнень із фрізичної підготовки [18].

«Симуляційні ігри» («Simulation»). Якщо дітям буде запропоновано дізнатися про римську історію, читаючи, дивлячись фільми, беручи участь у дискусіях або перебуваючи в ролі громадянина Римської імперії, то, безумовно, вони виберуть комп'ютерну імітаційну гру. За допомогою імітаційних ігор діти перестають бути пасивними одержувачами інформації, а стають активними учасниками смислового досвіду, коли переносяться в інший час, місце або реальність. Імітаційні ігри є реальною можливістю здійснювати домашнє навчання на основі відео-ігрового підходу. Гравці повністю занурюються у віртуальне навчальне середовище і розвивають комплексне глибоке розуміння віддалених у часі подій [18].

Симуляційні ігри, такі, як «Володар американських гірок» («Roller Coaster Тусооп»), дають гравцям відчуття того, що потрібно для великого бізнесу. У грі «Sim City» гравці можуть розвинути глибоке розуміння процесу міського планування та розбудови інфраструктури. Змагання щодо розбудови «Міста майбутнього» надає дітям можливість робити те, чим займаються інженери, - визначати проблеми; здійснювати мозковий штурм ідей; проектувати реалізацію прийнятого рішення; тестувати, повторно тестувати та будувати; обмінюватися своїми результатами з іншими, - все це в ігровій реальності «Sim City» [18].

Масові он-лайн рольові ігри для багатьох гравців (MMORPGs ), на думку педагогів і батьків, $€$ найефективнішими для домашнього навчання. Гра «World of Warcraft» спочатку використовувалася в позашкільних освітніх практиках у рамках проекту для учнів середніх шкіл. Метою проекту було з'ясування можливостей гри щодо фрормування в учнів мовних, математичних компетентностей, а також засад етичної поведінки цифрових громадян та безпечного користування Інтернетом. Після успішних результатів реалізованого проекту ця гра була визнана як така, що відповідає освітнім стандартам і рекомендована для використання як домашнім, так і шкільним учням [18].

Граючи разом у гру «Minecraft», батьки і діти беруть участь у незвичайних пригодах і водночас вивчають основи природознавства, технологій, інженерії, математичних досліджень. Також гра $є$ корисною для вдосконалення комунікативних умінь, для дослідження специфіки фрункціонування різних видів суспільств, i, що особливо цікаво, для гравців є можливим відтворити та на власному ігровому досвіді безпосередньо відчути життя стародавніх цивілізацій [18].

До найбільш популярних у середовищі домашньої освіти комп'ютерних ігор належать «Володар зоопарку» («Zoo Tycoon»), «Вік міфології» («Age of Mythology»), «Сіммси» («The Simms»), («Runescape») [8].

У грі «Володар зоопарку» («Zоo Тусооп») гравець створює свій власний зоопарк і забезпечуєте його діяльність. Гра надає досить багато інформації про тварин, і діти повинні дізнатись, що потрібно кожній тварині (їжа та простір) для забезпечення ії щасливого життя. Одним із позитивних ефектів застосування цієї комп'ютерної гри є стимулювання уяви і фантазії.

Гра «Вік міфології» ознайомлює з багатством єгипетської, норвезької та грецької міфрології. Батьки стверджують, що саме ця гра прищепила їхнім дітям захоплення єгипетською історією. Саме гра стимулювала відвідування дітьми музеїв для вивчення артефактів, перегляд багатьох документальних фрільмів, а також читання книжок відповідної тематики. За словами батьків, гра ініціювала дослідницький проект з вивчення міфології.

Діти, насолоджуючись грою «Сіммси», засвоювали базові знання з економіки, здобували вміння, як утримувати сім'ю. Пізніше у них виникло бажання мати справу з цілим поселенням родин, а не тільки виключно з однією сім'єю. Для цього вони розробили паперову гру, в якій функціонувало ціле місто родин. Гра передбачала повний економічний цикл, коли бідні отримували можливість стати багатими, а заможні спробували попрацювати на робочих місцях із низькою платнею. 
Гра «Runescape» спочатку викликала підозри щодо освітніх можливостей, проте батьки визнали, що не можна заперечувати навчальні переваги, які вона має. Гра стимулювала дітей досліджувати процеси, що відбуваються в гірничій справі, шукати відповіді на запитання, яким чином вироблялися метали. Було розроблено навчальний гірничо-видобувний проект, який охопив таку тематику: «Доісторична гірнича справа»; «Єгипетська гірнича справа»; «Золота лихоманка»; «Вікторіанський видобуток»; «Сучасний видобуток». Під час читання книжок, перегляду відео- та екскурсій на шахти учні використовували знання, які отримали у процесі гри. Для дітей стало звичним переглядати періодичну таблицю і їх зацікавив збір різних видів металів. Чим більше діти грали в цю гру, тим частіше шукали порад в Інтернеті про те, як краще грати. Це спонукало їх створити власні блоги спочатку про видобування залізних руд, а пізніше про інші цікаві для них теми.

Діти також хотіли розробити власну версію гри. Вони багато дискутували про уявні світи, які створять, і про завдання, якими доповнять сценарій гри. Учні накреслили карти, обговорювали можливості програмування. Разом з батьками діти почали вивчати мови програмування для дітей і створювати власні (елементарні) ігри.

Більшість батьків вважає, що комп'ютерна гра може бути чудовим доповненням до домашнього навчання, хоча не варто забувати про можливі шкідливі наслідки [8].

Звичайно, грати навіть у такі захопллючі ігри тривалий час без перерв, фрізичних вправ є шкідливим. Але якщо порівняти традиційні підходи до навчання, які передбачають прочитання розділу і надання відповідей на поставлені питання, то навчання на основі використання комп'ютерних ігор вирізняється привабливими освітніми можливостями: створення власних героїв, участь в історичних баталіях, польоти, дослідження, знаходження планів, представлення результатів.

У своєму блозі П. Грей підбив підсумки аналізу загальних побоювань щодо відеоігор (викликають звикання та сприяють таким хворобам, як соціальна ізоляція, ожиріння та насильство), а також вказав на те, що ігри можуть допомогти дітям розвинути логічні, мовні, літературні та навіть соціальні навички. П. Грей наголосив на когнітивних перевагах таких ігор [6].

Грунтючись на дослідженнях Адама Ейхенбаума, Дафна Бав'єєра та К. Шона [9], Гріна, учений фрормулює положення, що підтверджують позитивний вплив ігор на розвиток гравців. Наведемо їх:

- покращення основних візуальних процесів;

- покращення чутливості до візуальної контрастності;

- успішне лікування амбліопії (амбліопія, так зване «ліниве око», - це розлад, що виникає в ранньому дитинстві, коли одне око стає суттєво нефункціональним; експерименти підтвердили, що ті, хто опинився в умовах гри, показали значне поліпшення - часто до нормального або майже нормального функціонування);

- поліпшення уваги та пильності;

- покращення здатності відстежувати рухомі об'єкти в полі зору;

- зниження імпульсивності (гравці покращили здатність утримуватися від реагування на нецільові стимули);

- подолання дислексії (дослідження показали, що лише 12 годин відеоігор покращили вміння дітей читати, при цьому поліпшення було настільки ж великим або більшим, ніж досягнення навчальних програм, спеціально розроблених для лікування дислексії);

- покращення виконавчого функціонування (виконавче функціонування - це здатність людини розподіляти свої психічні ресурси (такі, як сприйняття, увага, пам'ять) таким чином, що дозволяє швидко та ефективно вирішувати проблеми або приймати рішення). Збільшення психічної гнучкості (дослідження показали, що досвід роботи з відеоіграми покращує здатність швидко і без помилок реалізувати завдання, які містять суперечливі вимоги);

- покращення навичок, пов'язаних з виконанням когнітивних завдань (дослідження вказують на те, що відеоігри можуть розвивати інтелект швидше та ефективніше, ніж будь-який інший спосіб, раніше створений) [6].

Цікавими є рекомендації, які дає П. Грей батькам учнів. У рекомендаціях учений наголошує, що інформація про шкідливі ефекти комп'ютерних ігор переважно міфічна, а позитивні ефекти реальні, особливо стосовно формування цифрових умінь, які стають все більш важливими в сучасному світі [6].

Заслуговує на увагу те, що П. Грей та інші автори блогів, присвячених використанню комп'ютерних ігор у домашньому навчанні, заохочують батьків узяти участь в обговоренні таких питань: Який досвід $є$ у вас чи ваших дітей у відеоіграх? Які ваші думки та питання стосовно цього? [6].

Доктор Джеймс Пол Джі, провідний фрахівець із питань використання комп'ютерних ігор в освітніх практиках в Університеті штату Арізона, зазначає, що «виникли нові теорії, які полягають у тому, що люди навчаються на досвіді (наш мозок зберігає кожен досвід, який ми отримали), і це є ключовим положенням щодо визначення факторів впливу на навчальний процес. Якщо проаналізувати навчальний досвід, якого діти набувають через ігри, то закономірним є висновок про значний освітній потенціал комп'ютерних ігор» [10, с. 32].

Більшість зарубіжних фрахівців із використання комп'ютерних ігор в освіті, й зокрема в домашньому навчанні, наголошує на їх високому педагогічному потенціалі, що виявляється в наступному: розвиток когнітивних, креативних, соціальних, технологічних умінь. Водночас серйозною перешкодою для їх широкого застосування в домашньому навчанні $€$ побоювання батьків щодо набуття дітьми ігрової залежності. Науковці, які досліджують 
проблеми ігрової залежності, наголошують, що причиною хворобливого стану є власне не гра, а проблема, від вирішення якої дитина починає ховатися у віртуальному світі [14]. Такі висновки стимулюють до використання ігор у навчанні й водночас потребують широкого розповсюдження серед громадськості.

\section{ВИСНОВКИ ТА ПЕРСПЕКТИВИ ПОДАЛЬШИХ ДОСЛІДЖЕНЬ}

Аналіз зарубіжного досвіду свідчить про доцільність використання комп'ютерних ігор у домашньому навчанні. Характеристика змісту найбільш уживаних у домашній освіті ігор, аналіз статей, блогів науковців, батьків домашніх учнів дає підстави виокремити позитивні ефекти використання ігор у домашньому навчанні.

Відеоігри стимулюють навчальний процес, бо діти грають для розваги з метою просування на наступний рівень, підкорення суперника та подолання викликів і в ході гри вирішують задачі на основі аналізу даних у різних ситуаціях. Відеоігри мають усі компоненти, що забезпечують ефективне навчання: мотивація, чіткі цілі та правила, інтерпретовані результати та постійний зворотний зв'язок.

Навчання й оцінювання функціонально пов'язані в грі, адже не можна перейти з одного рівня на інший, поки не будуть виконані всі необхідні завдання, таким чином відпадає необхідність у тестуванні.

Відеоігри стимулюють дітей до пошуку і приймання викликів. Якщо ігрові рівні важко освоїти, то часто це створює додаткову мотивацію для гравців щодо оволодіння новими вміннями.

Граючи у відеоігри, діти відчувають набагато менший стрес від ризику програти, ніж під час традиційного навчання. Якщо учень програв, то він отримує можливість знову здійснити складні ігрові дії, уникаючи при цьому негативного оцінювання.

Один із найбільших плюсів щодо використання навчальних ігор полягає в тому, що вони дозволяють дітям просуватися через ігрові рівні у власному темпі. Ігри дозволяють на практиці реалізувати індивідуалізоване навчання. 3 кожною новою грою знання та досвід, отримані в попередніх іграх, можуть бути застосовані дітьми для отримання нового досвіду.

Таким чином, використання комп'ютерних ігор у домашньому навчанні створює умови для розвитку в дітей умінь, необхідних для життя в XXI столітті, а саме: когнітивні, креативні, комунікативні, колаборативні та технологічні вміння. Вирішальним фактором на користь використання комп'ютерних ігор є те, що навчання стає привабливим для дітей, активізує у них природну потребу пізнання. Можливі ризики використання комп'ютерних ігор можна знівелювати, якщо дотримуватися гігієнічних вимог щодо організації навчання дітей.

Подальшого дослідження потребує зарубіжний досвід використання комп'ютерних ігор у процесі вивчення мистецьких дисциплін.

\section{СПИСОК ВИКОРИСТАНИХ ДЖЕРЕЛ}

[1] Биков В., Лещенко М. Цифрова гуманістична педагогіка відкритої освіти. Теорія і практика управління соціальними системами. 2016. № 4. C. 115-130. URL: http://nbuv.gov.ua/UJRN/Tipuss_2016_4_13

[2] Гринько В. Професійна компетентність учителя в сучасному інформаційному суспільстві. Педагогічні науки: теорія, історія. Суми: Вид-во СумДПУ імені А. С. Макаренка, 2017. № 8 (72). С. 246-258.

[3] Лещенко А. Домашнє навчання в системі професійної освіти США [Рукопис] : дис. ...... канд. пед. наук, Ін-т педагогіки і психології проф. освіти АПН України. Київ, 2006. 203 с.

[4] Лещенко П. А. Зарубіжний досвід використання відео ігор у навчанні старшокласників. Педагогічні науки: теорія, історія, інноваційні технології. 2017. № 8 (72). С. 85-93.

[5] Рубан Л. Домашнє навчання як альтернативна форма здобття початкової освіти (за ідеями американського педагога Джона Холта). Порівняльно-педагогічні студії. 2014. № 6(20). С. 161-168.

[6] Cognitive Benefits of Playing Video Games (2015) | Psychology Today Retrieved from https://www.psychologytoday.com/. I freedom-learn/.../cogn...

[7] edugame Розумники (2015) Retrieved from edugames.rozumniki.ua/

[8] Effects of Computer Games - Homeschooling-Ideas (2017) Retrieved from www.homeschooling-ideas.com/ effects-of-computer-games. ).

[9] Eichenbaum, A. E., Bavelier, D., \& Green, C. S. (2014). Video games: Play that can do serious good. American Journal of Play, 7, 50-72.

[10] Gee, J., P. (2007) What Video Games Have to Teach Us About Learning and Literacy. St. Martin's Griffin; 2nd edition, 2007,256 p.

[11] Gray, P. (2015). Free to Learn: Why Unleashing the Instinct to Play Will Make Our Children Happier, More Self-Reliant, and Better Students for Life - Basic Books; 1 edition,- 288 pages.

[12] Home education on the rise in Europe - Homeschooling - WORLD (2017) Retrieved from https://world.wng.org/. / home_education_on_the_rise_in_e...

[13] Homeschooling in the United States(2017)|Revolvy, Retrieved from https://www.revolvy.com/main/index.php?s...in+the...

[14] Loton, D. (2016). Video game addiction, engagement and symptoms of stress, depression and anxiety: The mediating role of coping. International Journal of Mental Health and Addiction, 14, 565-578.

[15] McGonigal, J.(2011) Reality Is Broken: Why Games Make Us Better and How They Can Change the World - The Pengiun Press, New York - $388 \mathrm{p}$.

[16] Prensky, M.(2001) Digital game-based learning. New York : McGraw-Hill, 2001. - 442p.

[17] Rolstad,K.\&Kesson, K. (2013) Unschooling, Then and Now Journalof Unschooling and Alternative Learning. - Vol. 7 (14) - $28-71$.

[18] Video Games | Penelope Trunk Education(2016) Retrieved from education.penelopetrunk.com/category/video-games/ 


\section{REFERENCES (TRANSLATED AND TRANSLITERATED)}

[1] Bykov V., Leshhenko M. Cyfrova ghumanistychna pedaghoghika vidkrytoji osvity (Digital humanistic pedagogy of open education). Teorija i praktyka upravlinnja socialjnymy systemamy. 2016. № 4. S. 115-130. URL: http://nbuv.gov.ua/UJRN/Tipuss_2016_4_13 (in Ukrainian)

[2] Ghrynjko V. Profesijna kompetentnistj uchytelja v suchasnomu informacijnomu suspiljstvi (Professional competence of the teacher in the modern information society). Pedaghoghichni nauky: teorija, istorija. Sumy: Vyd-vo SumDPU imeni A. S. Makarenka, 2017. № 8 (72). S. 246-258. (in Ukrainian)

[3] Leshhenko A. Domashnje navchannja v systemi profesijnoji osvity SShA (Home Education in the US Professional Education System USA) [Rukopys] : dys........kand. ped. nauk, In-t pedaghoghiky i psykhologhiji prof. osvity APN Ukrajiny. Kyjiv, 2006.203 s. (in Ukrainian)

[4] Leshhenko P. A. Zarubizhnyj dosvid vykorystannja video ighor u navchanni starshoklasnykiv. (Foreign experience in the use of videogames in the teaching of senior pupils). Pedaghoghichni nauky: teorija, istorija, innovacijni tekhnologhiji. 2017. № 8 (72). S. 85-93. (in Ukrainian)

[5] Ruban L. Domashnje navchannja jak aljternatyvna forma zdobttja pochatkovoji osvity (za idejamy amerykansjkogho pedaghogha Dzhona Kholta) ) (Home education as an alternative form of primary education (based on the ideas of the American educator John Holt). Porivnjaljno-pedaghoghichni studiji. 2014. № 6(20). S. 161-168. (in Ukrainian)

[6] Cognitive Benefits of Playing Video Games (2015) | Psychology Today Retrieved from https://www.psychologytoday.com/. / freedom-learn/.../cogn. .... (in English)

[7] edugames - Rozumnyky (Clevers) (2015) Retrieved from edugames.rozumniki.ua/(in Ukrainian) (in English)

[8] Effects of Computer Games - Homeschooling-Ideas (2017) Retrieved from www.homeschooling-ideas.com/effects-of-computergames. ). (in English)

[9] Eichenbaum, A. E., Bavelier, D., \& Green, C. S. (2014). Video games: Play that can do serious good. American Journal of Play, 7, 50-72. (in English)

[10] Gee, J., P. (2007) What Video Games Have to Teach Us About Learning and Literacy. St. Martin's Griffin; 2nd edition, 2007, 256 p. (in English)

[11] Gray, P. (2015). Free to Learn: Why Unleashing the Instinct to Play Will Make Our Children Happier, More Self-Reliant, and Better Students for Life- Basic Books; 1 edition,- 288 pages. (in English)

[12] Home education on the rise in Europe - Homeschooling - WORLD (2017) Retrieved from https://world.wng.org/. /home education_on_the_rise_in_e. (in English)

[13] Homeschooling in the United States (2017)|Revolvy, Retrieved from https://www.revolvy.com/main/index.php?s...in+the. .. (in English)

[14] Loton, D. (2016). Video game addiction, engagement and symptoms of stress, depression and anxiety: The mediating role of coping. International Journal of Mental Health and Addiction, 14, 565-578. (in English)

[15] McGonigal, J. (2011) Reality Is Broken: Why Games Make Us Better and How They Can Change the World - The Pengiun Press, New York - 388 p. (in English)

[16] Prensky, M. (2001) Digital game-based learning. New York: McGraw-Hill, 2001.- 442p.

[17] Rolstad, K.\&Kesson, K. (2013) Unschooling, Then and Now Journal of Unschoolingand Alternative Learning. - Vol. 7 (14) - 2871. (in English)

[18] Video Games | Penelope Trunk Education (2016) Retrieved from education.penelopetrunk.com/category/video-games/ (in English)

Рецензент: Луцан Н.І., доктор педагогічних наук, професор, ДВНЗ «Прикарпатський національний університет імені Василя Стефаника» 